\title{
Supervision for School Psychologists in Training: Developing a framework from
} empirical findings

Simon Gibbs ${ }^{\mathrm{a}}$, Cathy Atkinson ${ }^{\mathrm{b}}$, Kevin Woods $^{\mathrm{b}}$ Caroline Bond $^{\mathrm{b}}$, Vivian Hill ${ }^{\mathrm{c}}$, Julia Howe ${ }^{\mathrm{d}}$ and Sue Morris ${ }^{\mathrm{d}}$

${ }^{a}$ School of Education, Comunication and Language Sciences, KGVI Building, University of Newcastle, NE1 7RU, UK; simon.gibbs@newcastle.ac.uk

b School of Environment, Education and Development, Ellen Wilkinson Building, University of Manchester, M13 9PL, UK; cathy.atkinson@ manchester.ac.uk; kevin.woods@manchester.ac.uk; caroline.bond@manchester.ac.uk

${ }^{\mathrm{c}}$ Psychology \& Human Development, UCL Institute of Education University College London, 25 Woburn Square, London WC1H 0AA, UK; v.hill@ioe.ac.uk

${ }^{\mathrm{d}}$ School of Education, University of Birmingham

Edgbaston, Birmingham, B15 2TT, UK; j.howe.1@bham.ac.uk, s.k.morris@bham.ac.uk

\footnotetext{
${ }^{1}$ Corresponding author
} 


\title{
SUPERVISION FOR SCHOOL PSYCHOLOGISTS IN TRAINING
}

\begin{abstract}
Similar to other professional disciplines, the importance of supervision within school psychology has attracted considerable attention within recent years. Despite this, systematic review of current literature reveals a dearth of empirical literature proposing underlying theoretical structures. This study extends recent qualitative research by surveying 310 school psychology students undertaking a preparatory doctoral training programme within the 12 approved universities in England and Wales. Data were obtained from a 21-item closed questionnaire developed from previous empirical findings and subjected to Exploratory Factor Analysis. Findings reveal three key supervisory components: safe space for authentic learning, instructional support, and reference points for professional learning. Comparisons with other theoretical models are made and implications for practice explored. A framework for professional practice, based on key findings and other important theoretical developments, is proposed.
\end{abstract}

Keywords: competencies, model, trainee, training, supervision 


\section{SUPERVISION FOR SCHOOL PSYCHOLOGISTS IN TRAINING}

\section{Introduction}

\section{Supervision of school psychologists}

The increasing body of literature surrounding the supervision of school psychologists ${ }^{2}$ is a relatively new phenomenon, given that less than two decades ago, Crespi and Fischetti (1997) bemoaned not only the scant literature on school psychology supervision, but of supervision in general. The impetus for this may partly reside within increasing emphasis on quality assurance and guidance on supervisory practices for practitioner psychologists (e.g. Health and Care Professions Council (HCPC), 2014; National Association of School Psychologists (NASP), 2010). Annan and Ryba (2013) advocated the fundamental importance of supervision to sound professional practice in school psychology, while Smith Harvey and Pearrow (2010) suggested that it is imperative for professional growth and skill development. Sayeed and Lunt (1992) and Smith Harvey and Stuzziero (2008) suggested that for school psychologists, supervision should be a long term, if not life-long activity. Despite this, internationally there have been consistent reports of school psychologists receiving insufficient or inadequate supervision (Chafouleas, Clonan, \& Vanauken, 2002; Crespi \& Dube, 2006; Lam \& Yuen, 2004; Thielking, Moore, \& Jimerson, 2006). The work reported in this paper provides evidence about important components of supervision for psychologists in training and how the relative importance of these components changes during training. It thus goes some way to offering a rationale for supervision in practice.

Debate is ongoing regarding access to clinical supervision that develops the professional skills of school psychologists. In contrast, administrative supervision refers to accountability and evaluation, involving tasks such as record keeping and adherence to policies (Chafouleas

\footnotetext{
${ }^{2}$ In the UK, school psychologists are referred to as educational psychologists (EPS) and have a role working with children and young people aged 0-25 in school and community settings. School psychologists in training are referred to as trainee educational psychologists. All EPs undertake a three-year doctoral training route to becoming registered practitioners.
} 


\section{SUPERVISION FOR SCHOOL PSYCHOLOGISTS IN TRAINING}

et al., 2002; Crespi \& Fischetti, 1997, Dunsmuir \& Leadbetter, 2010). Evaluation is also a function of clinical supervision, but focuses on developing the professional skills of the trainee; whereas administrative evaluation concerns the functioning of the organisation and is consistent with legal, contractual and organizational practices.

Within the literature, the supervision of school psychologists falls into three main areas (Dunsmuir \& Leadbetter, 2010). These are: the supervision of practising school psychologists (e.g. Annan \& Ryba, 2013; Chafouleas, Clonan, \& Vanauken, 2002; Lam \& Yuen, 2004; Smith Harvey \& Pearrow, 2010; Thielking et al., 2006); the supervision of school psychologists in training (Atkinson \& Woods, 2007; Carrington, 2004; Haboush, 2003; Hill et al., 2015; Sayeed \& Lunt, 1992; Woods et al., 2015) and the supervision of professionals from other disciplines by school psychologists (Callicott \& Leadbetter, 2013; Maxwell, 2013; Osborne \& Burton, 2014). The empirical element of this paper focuses on the second of these, given that the need for supervision is considered to be particularly important during professional training and critical to ensuring both the effectiveness of practice placements and the experience of the trainee (Woods et al., 2015). However, in seeking to explore the theoretical models and approaches to supervision used by school psychologists, this study draws on literature from all three areas.

To date, the most systematic overviews of supervisory literature within school psychology have been provided by McIntosh and Phelps (2000) and Smith Harvey and Stuzziero (2008). The reviews indicated that articles focused on a number of areas: supervision practices within the field; congruence of supervision with professional standards; role of supervision within training programmes; provision of effective supervision; and the evaluation of models of supervision. Since the aim of this research was to explore core components of effective supervision, the focus henceforth will be an exploration of supervision competencies within school psychology practice and how these are delineated within supervision models. 


\section{SUPERVISION FOR SCHOOL PSYCHOLOGISTS IN TRAINING}

\section{Supervision competencies}

McIntosh and Phelps (2000) noted that few studies were empirically grounded and that none showed that supervision led to more effective school psychologists or more effective client outcomes. Accordingly, McIntosh and Phelps (2000) called for recognition of the complexity of school psychology supervision and for systematic research focused on developing better understanding of the facets of supervision. Internationally, the need for greater understanding of the skills involved in supervision has been increasingly recognised (Annan \& Ryba, 2013, Lam \& Yuen, 2004; Papacosta, 2007), with Simon, Cruise, Huber, Swerdlik, \& Newman (2014) outlining some of the key developments over the last decade in improving the identification and assessment of supervision competencies. Two examples are provided below.

In the UK, Dunsmuir and Leadbetter (2010) assembled a working group of school psychologists to develop practice guidelines for supervisors and defined specific supervisor competencies across six levels: training, values, context, knowledge, skills and evaluation. More recently, the American Psychological Association (APA) (2014) produced supervision guidance, following work by a convened task force. Guidelines on supervision are organised across seven domains, the first of these being Supervisor Competence. This made explicit the need to identify supervision as a distinct area of practice, requiring specific and ongoing training and skill development. However, while both documents offer frameworks for enhancing supervisory competence, both are based on practice review rather than empirical research. Furthermore, it could be argued that they are based on the views of experienced supervisors, rather than the experiences and needs of supervisees.

One issue with applying competency frameworks is that although they are very comprehensive (e.g., APA (2014) highlights 25 competencies across five domains; Dunsmuir \& Leadbetter (2010) highlights 57 competencies across six domains), because of this, they 


\section{SUPERVISION FOR SCHOOL PSYCHOLOGISTS IN TRAINING}

are potentially not easy to internalise, review or to use as a practice guidance framework. To this extent, incorporating them into theoretical models may be one way of improving accessibility (Simon et al., 2014). The following section explores the use of supervision models within school psychology. It should be noted that the identification of competencies and key features of supervision is often central to the development of these models.

\section{Supervision models}

Historically, school psychology supervision models were adopted from other disciplines (Simon et al., 2014). Newman (2013) noted that while there was plentiful literature about their existence within mental health fields, it was unclear which should be advocated given insufficient evidence of effectiveness. Callicott and Leadbetter (2013) observed that most models of supervision used within school psychology were triadic, with functions broadly described as 'educative', 'supportive' and 'managerial.' Whilst an overview of the numerous models used in school psychology practice is beyond the scope of this paper, a few, designed specifically for use by school psychologists, are worthy of further consideration.

Atkinson and Woods' (2007) Model of Effective Supervision for trainee school psychologists was developed following a survey of 93 English supervisors and facilitators and barriers to effective supervision. The model proposes triadic functions of guidance, problem solving and support within a context of school psychology practice. However, the formulation of the model from the empirical data is unclear and the position of the trainee within the model weak (Callicott \& Leadbetter, 2013). Simon et al. (2014) drew on developmental and systemic supervisory models (Holloway, 1995; Stoltenburg \& McNeill, 2009) in proposing the Developmental/Ecological/Problem-Solving (DEP) Model for use by both trainee and practising school psychologists, which also incorporated reference to core professional competencies (Fouad et al., 2009; NASP, 2010). Its derivation was transparent and linked to psychological and systems theory. Hill et al., (2015) proposed that focus group 


\section{SUPERVISION FOR SCHOOL PSYCHOLOGISTS IN TRAINING}

findings from interviews with UK school psychologists undertaking doctoral training offered support for the relevance of the DEP Model. However, it should be noted that Hill et al.(2015) did not specifically aim to evaluate the DEP and conclusions were based on retrospective analysis with reference to the model. The DEP Model could therefore be criticised for a lack of empirical derivation and validation.

Two recent studies have employed a more systematic approach to identifying dimensions of supervision and presenting supervision models. Using ecological analysis involving review of pre-existing literature, supervision documentation, and semi-structured interviews, Annan and Ryba (2013) studied the views of 31 school psychologists in New Zealand. They were able to examine aspects of practice, previously well-represented in supervision literature, specifically: purpose, concept of supervision, support and knowledge, accountability and satisfaction with supervision. Results were reported as three interrelated dimensions of supervision: theories of supervision and practice; contemporary practice (e.g. different forms of supervisory engagement, incorporating formal and informal practices); and mediators (e.g. professional connections, contextual knowledge and interpersonal relationships). Within the paper these were developed as a triadic model, incorporating subthemes from the data analysis. The dimensions were informed by literature review, semi-structured interviews and analysis of written records (e.g. reports). Subthemes falling within each of the dimensions were described in more detail. The research appears transparent and systematic and wellinformed by previous literature. However, possible criticisms of the research are that the three dimensions were defined at the outset, rather than emerging from research, and the methodology approach used to harness 'contemporary supervision practice' (semi-structured interviews with school psychologists) seems more systematic and robust than the approach used to define the other dimensions. 


\section{SUPERVISION FOR SCHOOL PSYCHOLOGISTS IN TRAINING}

In a study from England, Woods et al. (2015) explored the needs and experiences of school psychologists undertaking three-year professional doctorate training in four of the 12 English universities offering the programme. The design extended previous research by Heaney (2010), comprising 12 focus groups (involving a total of 111 trainee psychologists) representing each training year group (Year 1, Year 2 and Year 3) at each of the universities. Transcript data were systematically coded using a three-stage process that yielded seven core themes, presented as a model of factors contributing to supervision (see Figure 1). More detail about the key concepts emerging within each of these themes can be found in Table 1 below.

\section{(Figure 1 about here)}

The research reported here used the seven themes and data from the earlier study (Woods et al., 2015) as the basis for a questionnaire survey, aiming to evaluate the generalisability and coherence of findings from the previous qualitative investigation. In doing so, it posed the following research question:

To what extent are different supervisory factors prioritised and valued by school psychologists at different stages of training?

\section{Method}

\section{Design}

Following the initial exploratory study (Woods et al., 2015) a survey questionnaire was developed using the seven main themes identified in the focus groups. Key concepts emerging within each of the seven themes were used to guide the development of the survey items (see Table 1). These were discussed and agreed to at a face-to-face meeting of the research team.

(Table 1 about here) 


\section{SUPERVISION FOR SCHOOL PSYCHOLOGISTS IN TRAINING}

The purpose of the questionnaire was twofold: to survey the extent to which aspects of the initially observed themes were represented more widely, and to provide quantitative validation of the initially identified themes. As far as possible, questionnaire items were derived verbatim from the focus groups with each of the seven original themes represented by three questionnaire items. Items were selected by the research team to capture material that arose most frequently in the focus groups and was thought to best represent each of the main themes most accurately. An initial survey questionnaire was developed for evaluation by the research team, to achieve agreement on the items that most effectively and comprehensively encapsulated and differentiated the core/ aspects of each of the seven original themes. The final questionnaire, showing how the 21 items link to the themes derived in the Woods et al. (2015) research are available as Online Supplemental Material to this paper. An additional item provided an open opportunity for comment on other supervision-related matters that respondents wished to draw to our attention. In this paper we will only treat responses to the 21 'closed' items. Responses were invited on a 5 point Likert scale. It is acknowledged that Likert-type data are ordinal and the intervals between points on the survey scales cannot be assumed to be equal. For this reason, only the anchor points 'Totally disagree' and 'Totally agree' were provided and respondents asked to give a numerical, rather than a descriptive

rating. Demographic data were collected to provide information on each trainee's phase of training, gender, and age.

\section{Participants}

The programme directors of the 12 doctoral training programmes in English universities were asked to distribute the questionnaire to all trainee school psychologists enrolled on their respective programmes. University Research Ethics Committee approval was granted following submission of details of the methodological approach and survey instrument. Participants were assured they did not need to take part in the study and could choose not to 


\section{SUPERVISION FOR SCHOOL PSYCHOLOGISTS IN TRAINING}

complete the questionnaire without prejudice. Questionnaires were completed anonymously in paper-based format and returned to the first author for analysis. Respondents were informed that in returning the questionnaire, they gave consent to participate in the study. A total of 311 responses were received, providing a very high overall representative response rate $(84 \%)$. Of these 111 responses were received from trainees in their first year, 99 from trainees in the second year and 101 responses from trainees in their third (final) year of training. Broadly reflecting the current demographics of psychologists in training in the UK (National College for Teaching \& Leadership, 2013), the majority of respondents were female (80\%), and the modal declared age of all respondents was 26 years. See Table 2 (Online Supplementary Material) for full demographic information.

\section{Analysis}

To provide an overview of current prioritisation of the elements of effective supervision, mean Likert ratings for each of the 21 questionnaire items were calculated and evaluated, with particular focus upon elements (questionnaire items) receiving mean ratings below the mid-point rating ('3’) (see Table 3 below).

To test the underlying structure of the questionnaire responses, exploratory factor analysis (EFA) was undertaken. Preliminary tests of the data indicated the data were suitable for EFA $\left(\right.$ Kaiser-Meyer-Olkin $(\mathrm{KMO})=.92$; Bartlett's test of sphericity, $\left.\chi^{2}=2588.3, \mathrm{p}<.001\right)$ and the questionnaire showed good overall internal consistency $(\alpha=.87)$. Factors were extracted using EFA and, as we expected some correlation of the components, subject to oblique (direct oblimin) rotation (see also Table 3 below). The initial solution indicated five components with eigenvalues greater than 1 . Whilst this solution accounted for $59.2 \%$ of the variance, it was dominated by an initial large eigenvalue (7.79). Further, the scree test also suggested that at most three components were viable. Accordingly a three component solution was requested. The extracted components accounted for $49.4 \%$ of the variance. 


\section{SUPERVISION FOR SCHOOL PSYCHOLOGISTS IN TRAINING}

On inspection of the reliability coefficients in the preliminary analyses and the item factor loadings, Item 9 was deleted. The matrix for the remaining 20 Likert-scale items had $\mathrm{KMO}=.928$ and Bartlett's test of sphericity $=2542.8(\mathrm{p}<.001)$. The analysis was repeated and the resulting three component solution accounted for $51.19 \%$ of the variance.

\section{Findings}

Descriptive analysis of the survey responses (see Table 3 column 3 ) showed that 17 out of 21 questionnaire items had a mean response above the scale mid-point (' 3 ') suggesting that these elements of effective supervision were being effectively prioritised in supervision at the time of the survey. Four items $(2,3,6,20)$ received a mean rating below the mid-point (range 2.2-2.85) suggesting the use of models/ frameworks in supervision, feedback on practice, and opportunities for co-working with the supervisor, are areas for development within the current context for effective supervisory practice within UK school psychology preparation.

The EFA solution to the pattern of questionnaire responses is presented below in Table 4 (in which for ease of interpretation item-factor loadings <.3 have been omitted (Stevens, 2002)). Items in Component One appeared to relate to both relationship and service context factors (e.g. role clarity, protected opportunities for supervision) which helped trainee school psychologists to feel supported and secure. This component was therefore titled 'safe space for authentic learning'. Component Two ('instructional support'), linked items associated with more direct support, while Component Three appeared to allude to external areas for guidance and was named, 'reference points for professional learning'.

(Table 3 about here)

(Table 4 about here)

\section{Components perceived as most important}




\section{SUPERVISION FOR SCHOOL PSYCHOLOGISTS IN TRAINING}

The three components were converted to percentages of their maximum (since they consisted of different numbers of items) and a within subjects MANOVA was performed to test if any factors were more important than others. The analysis indicated a significant interaction between year group and supervision components (Pillai's Trace F=7.5, $\mathrm{p}<.001$ ) and a significant main effect of component (Pillai's Trace F=204.3, $\mathrm{p}<.001$ ). Pairwise comparisons (with Bonferroni correction) suggested that there were significant differences between each of the factors and that a 'safe space for authentic learning' was the most important factor overall (see Table 6). The results are also presented graphically to illustrate the discussion (see Figure 2 below). Post-hoc tests indicated that significant differences across year groups were found only for 'instructional support,' and that this was most highly valued in Year 1 of training.

(Table 6 about here)

\section{Discussion}

The discussion focuses first on the three factors derived from the questionnaire analysis, considering each in relation to the pre-existing literature on school psychology supervision. It then considers these outcomes in light of previous empirical research and proposed theoretical models, before considering implications for school psychology practice.

In considering the themes found in the questionnaire responses we think it important to note their inter-relationship and relative importance changes with stage of professional development. This is graphically illustrated in Figure 2.

\section{(Figure 2 about here)}

The theme rated most highly, a 'safe space for authentic learning' reflects previous findings from supervisory literature. In clinical psychology training the supervisor's ability to establish a 'safe base' for the trainee has been recognised as being of paramount importance in enabling trainees to discuss salient concerns (Palomo, Beinart, \& Cooper, 


\section{SUPERVISION FOR SCHOOL PSYCHOLOGISTS IN TRAINING}

2010). Likewise, within psychotherapy supervision, the issue of 'non-disclosure' - raising issues that might not present the most favourable image of the trainee, including personal issues and adverse reactions to clients - is seen as a potential barrier to professional development (Ladany, 2004; Mehr, Ladany, \& Caskie, 2010). The findings of the present study, therefore, add validity to the emphasis placed on the emotionally supportive function of supervision found in several theoretical models (Atkinson \& Woods, 2007; Hawkins \& Shohet, 2006; Kadushin, 1992; Scaife 2009). Additionally they provide empirical support for competency statements related to supervisory 'values' defined by Dunsmuir and Leadbetter (2010), including 'Creating a safe and trusting forum for discussion and recognising potential power imbalances' and 'Being willing to expose vulnerabilities, discuss mistakes and take risks' (p. 15).

However, as 'safe space for professional learning' subsumes many of the themes identified in previous research (Woods et al., 2015) this may suggest that this notion extends well beyond other 'support' dimensions in the literature. This component includes a number of items that relate to feeling secure within the workplace ('Supervision helps me understand my role within the Local Authority ${ }^{3}$ '), within the training placement ('My supervisor is fully aware of the University requirements for the placement'), and within the supervisory relationship itself ('In supervision we explore possibilities'). This adds weight to the importance of models that fully acknowledge the significance of the context in which supervision occurs (Atkinson \& Woods, 2007; Holloway, 1995; Simon et al., 2014). It is also interesting to note that there are a number of items falling within this component, which could be potentially be classified as having an 'educative' function, such as 'Supervision helps me reflect on my learning and practice' and 'Supervision is helping integrate different

\footnotetext{
${ }^{3}$ Most UK school psychologists have a role working for a Local Authority, a local governmental administrative division, and have a role working across a number of schools and other educational settings.
} 


\section{SUPERVISION FOR SCHOOL PSYCHOLOGISTS IN TRAINING}

aspects of psychology in my practice'. It might also be predicted that professional and personal reflection might only really occur when the supervisee perceives supervision as a 'safe space'. This potentially highlights the need for the development of competence in supervision and supervisee evaluation (APA, 2014; Dunsmuir \& Leadbetter, 2010; Smith Harvey \& Stuzziero, 2008) both in establishing the 'safe space'; but also its parameters - for instance, when supervisors might need to take a supervisory issue to their own supervision (Dunsmuir \& Leadbetter, 2010).

In terms of previous models, those defining the functions of supervision in triadic terms have tended to identify a dichotomy between managerial/administrative functions, described as 'qualitative' (Hawkins \& Shohet, 2006), 'managerial' (Kadushin, 1992) and 'normative' (Scaife, 2009); and educative functions, labelled 'developmental' (Hawkins \& Shohet, 2006), 'educational' (Kadushin, 1992) and 'formative' (Scaife, 2009). Analysis of the items clustering within the remaining components of 'instructional support' and 'reference points for professional learning' suggest that there may be considerably greater overlap and that managerial/administrative and educative functions can co-exist, particularly in relation to professional practice and ethical guidance. Whilst not directly comparable, 'instructional support' and 'reference points for professional learning' may be more closely linked respectively to the 'guidance/monitoring' dimension (Atkinson \& Woods, 2007) or 'developmental' component (Simon et al., 2014). While these terms refer to formative and summative assessment functions within the supervisory relationship, when co-constructed and related to supervisee needs, these can have benefits in terms of pinpointing areas of strength, or for further development (Simon et al., 2014).

Exploring the components in turn, the significant differences between perceptions of 'instructional support' across years of training signal a developmental trend within this area. The fact that the importance for trainees of the instructional support component was 


\section{SUPERVISION FOR SCHOOL PSYCHOLOGISTS IN TRAINING}

significantly different across the three year groups suggests that its relevance to supervision is both dynamic and developmental. Furthermore, as previously discussed by Smith Harvey and Stuzziero (2008), the present results suggest that instructional support covers something broader than managerial/administrative direction or advice-giving and leans more towards the concept of a partnership, given that it includes items such as 'My supervisor and I sometimes co-work' and 'I receive regular feedback on my applied psychology practice, based on my supervisor's direct observation of my work.' However, it could be hypothesised that this analysis represents an over-simplistic picture of the developmental shifts and that these are potentially more fluid and dynamic across the course of doctoral training. As an example, it could be hypothesised that while 'In supervision my supervisor teaches me how to do specific work' might steadily decrease over time, that co-working could increase initially, then decrease, as part of a scaffolded learning experience. Additionally, greater need for 'instructional support' might arise where a supervisee is developing their skills within a new domain of practice (e.g. counselling/therapeutic work). A more accurate picture of development might therefore require analysis of activity at a greater number of timepoints, particularly in the early stages of training; and across different skill domains.

The present results also suggest that as the need for more direct instructional support diminishes, the value of both a 'safe space' and 'reference points for professional learning' increases. Salient here might be the usefulness of supervisors exploring how the concept of instruction versus support changes from an early need for a didactic approach, developing into knowledge, understanding and co-construction. This is also consistent with developmental models of supervision, such as the DEP (Simon et al., 2014) which refers to the supervisor role changing from 'teacher' to 'consultant' (p. 644).

Eshel and Koriat (2001) exemplify the role of 'directing supervision' as opposed to 'enabling supervision' for school psychologists, defining the former as follows: "In directing 


\section{SUPERVISION FOR SCHOOL PSYCHOLOGISTS IN TRAINING}

supervision, supervisors use their experience to show students how they coped with similar situations in the past or how they would have behaved had they encountered a similar situation" (p. 391). This description feels much closer to the elements of the "instructional support' component than to some of the potentially problematic directive or managerial/administrative supervision described by Smith Harvey and Pearrow (2010) and suggests that the 'managerial' or 'directive' component, could be defined differently in clinical and administrative supervision. Potentially this adds weight to Smith Harvey and Pearrow's (2010) argument that within school psychology, a model which takes account of both perspectives and is cognisant of systemic factors is appropriate and that all supervisory activity is co-constructed and related to supervisee need (Simon et al., 2014).

The final component - 'reference points for professional learning' - incorporates both models of professional practice and ethical guidance, but also appears to relate to specific feedback a supervisor might give in relation to professional expectations and standards. This element seems to include competencies associated with both 'values' and 'knowledge' identified by Dunsmuir and Leadbetter (2010). However, amongst trainee school psychologists in the current study, professional codes of conduct (e.g. British Psychological Society, 2010; Dunsmuir \& Leadbetter, 2010; HCPC, 2014) and theoretical models of supervisory practice appear strongly embedded in this function. Internationally, elements such as contracting, ethical and legal issues and obtaining professional/supervision are prevalent (e.g. Annan \& Ryba, 2013; Dunsmuir \& Leadbetter, 2010; Lam \& Yuen, 2004; Smith Harvey \& Pearrow, 2010; Thielking et al., 2006) and there is an increasing focus on developing models of school psychology supervision (Annan \& Ryba, 2013; Atkinson \& Woods, 2007; Simon et al., 2014). With this in mind, it is useful to speculate that for school psychologists, any educative function of supervision will be closely linked to frameworks which offer a clear and accountable process for professional development. 


\section{SUPERVISION FOR SCHOOL PSYCHOLOGISTS IN TRAINING}

While the relative importance of the three components varied across the three years, it is noteworthy that correlations between components were all positive and statistically significant. Also, within each cohort the correlations between components were also all positive and significant Online Supplementary Material. Thus we can infer that although the relative importance of components changes with stage of training, the extent to which supervision was valued by each trainee as a set of components remained relatively stable.

Interestingly, dimensions represented here and indeed in other relevant models (Annan \& Ryba, 2013; Atkinson \& Woods, 2007) do not specifically mention an evaluative component, as advocated by Dunsmuir and Leadbetter (2010). School psychologists in training in Woods et al's ( 2015) research alluded to this under the theme 'Outcomes', with some participants demonstrating an understanding of the meta-learning processes occurring within supervision. However, it is also important for supervisors to have a meta-perspective on their own supervisory practices (Dunsmuir \& Leadbetter, 2010) and this should therefore be incorporated to theoretical models.

From the results of the current study, the themes derived by (Woods et al., 2015) and from recognition of the developmental, contextual and socio-legislative factors which influence school psychology supervision, the authors propose the following framework (see Figure 3). It offers 'safe space for authentic learning' as an overarching component, with the other two dimensions represented as other key elements. Developmental and contextual factors are acknowledged and the need for evaluation is incorporated. The model could usefully benefit from further evaluation or empirical investigation and/or theoretical critique.

(Figure 3 near here)

\section{Limitations}

There are a number of limitations to this study. Firstly, given that the sample in this study comprises only school psychologists in training, more empirical research is required to 


\section{SUPERVISION FOR SCHOOL PSYCHOLOGISTS IN TRAINING}

discover if the supervisory needs of qualified school psychologists are comprehensively covered within these dimensions.

The developed theoretical model relies heavily upon the structure of the questionnaire, its interpretation by respondents, and from the analyses undertaken by the researchers which will be informed by perspectives gained from previous literature and research, particularly the study by Woods et al. (2015). Specificity of the present questionnaire could be enhanced by differentiating the meaning of the 'opinion' sought as relating to value rather than current experience; sensitivity could be improved by the addition of a item which asks trainee respondents to indicate their overall judgement of the level of effectiveness of their supervisory experience. Another limitation of the study is that all of the trainee school psychologists in this study were working within an English or Welsh context. Furthermore, all respondents in this research were engaged in a three-year doctoral training program. In many countries, school psychology training is at a different level (e.g. Masters) or of different duration (Jimerson, Oakland, \& Farrell, 2007) thus limiting the generalizability of the results. While the survey questions were generated from empirical research (Woods et al., 2015), it should be noted that this was solely within a UK context and that elements of other international supervisory models may not have been represented in the dataset and therefore within the questionnaire. Because the selection of questionnaire items had a significant impact on which aspects of different theoretical models of supervision were empirically supported, caution should be expressed about the international generalizability of these conclusions; and it should be recognised that the proposed model does not take account of possible contextual differences which would occur internationally, relating to the definition of the role, cultural factors and the socio-political context for the school psychologist's work.

\section{Future research}




\section{SUPERVISION FOR SCHOOL PSYCHOLOGISTS IN TRAINING}

It is possible that the context within which supervision takes place needs specific definition. For example, within UK practice guidelines, Dunsmuir and Leadbetter (2010) defined 12 different contextual factors which need to be taken account of, including 'clarifying lines of accountability and relationship between line management and supervision'; 'responding appropriately to legal and ethical issues'; and 'discussing supervision issues in the wider socio-political context' (p. 16). While these may be relevant internationally, further empirical research would be useful to establish the extent to which supervisory models are transferrable outside the context in which they have been developed, for example internationally or for other types of supervision, such as supervising other professionals.

It is clear that supervisory practice in school psychology is an area attracting increasing attention and stimulating debate. It is hoped that this study will promote further research in the field, potentially with different groups of participants (e.g. qualified school psychologists; other professionals) and across different national and international contexts, to develop and evaluate different supervisory models. Furthermore, the current research, like the study conducted by Woods et al. (2015) does not yet fully support an understanding of how and when supervisory elements are operationalised and indeed what effect this potentially has both on the effectiveness of supervision for both supervisor and supervisee. To some extent, we are still some way from the systematic research that addresses process, contextual and interpersonal variables that contribute to effective supervision advocated by McIntosh and Phelps (2000). Finally, additional support for the notion that supervision is important and vital to professional development and practice would come from evidence that supervision leads to more effective school psychologists or more effective client outcomes (McIntosh \& Phelps, 2000).

\section{Conclusions}




\section{SUPERVISION FOR SCHOOL PSYCHOLOGISTS IN TRAINING}

Within school psychology literature, this study represents the first representative, quantitative study of supervisory factors. The results indicate both parallels and differences with pre-existing models popular within school psychology and suggest the need to build upon work by Annan and Ryba (2013), Atkinson and Woods, (2007), Simon et al., (2014) and Woods et al., (2015) in developing models tailored specifically for school psychology practice. The developmental components of the model illustrated here and the apparent diminishing need for instructional support suggest that a model could exist which accommodates the supervisory needs of both training and qualified school psychologists throughout their professional career.

This research was conducted and the supervision framework developed within a UK context. Internationally there are concerns about coherent supervisory delivery models and structures (e.g. Annan \& Ryba, 2013; Lam \& Yuen, 2004; Papacosta, 2007; Smith Harvey \& Pearrow, 2010; Thielking et al., 2006) and it is possible that the framework proposed could provide a stimulus for discussions about how to develop practice in other countries. It is acknowledged that 'context and governance' factors will be particularly influential and may limit the transferability of the framework. However, given the developing international interest in supervisory competencies and models for school psychology practice and training, we hope that this paper will provide impetus for further international investigation. 


\section{References}

Annan, J., \& Ryba, K. (2013). Networks of professional supervision. School Psychology Quarterly: The Official Journal of the Division of School Psychology, American Psychological Association, 28(2), 170-82. doi:10.1037/spq0000015

APA. (2014). Guidelines for Clinical Supervision in Health Service Psychology. Washington, D.C: APA. Retrieved from https://www.apa.org/about/policy/guidelines-supervision.pdf

Atkinson, C., \& Woods, K. (2007). A Model of Effective Fieldwork Supervision for Trainee Educational Psychologists. Educational Psychology in Practice, 23(4), 299-316. doi:10.1080/02667360701660902

British Psychological Society. (2010). Guidance for educational psychology programmes in England, Northern Ireland and Wales. Leicester: BPS.

Callicott, K., \& Leadbetter, J. (2013). An investigation of factors involved when educational psychologists supervise other professionals. Educational Psychology in Practice, 29(4), 383-403. doi:10.1080/02667363.2013.853649

Carrington, G. (2004). Supervision as a reciprocal learning process. Educational Psychology in Practice, 20(1), 31-42. doi:10.1080/0266736042000180393

Chafouleas, S. M., Clonan, S. M., \& Vanauken, T. L. (2002). A national survey of current supervision and evaluation practices of school psychologists, Psychology in the Schools, 39(3), 317-325. DOI: 10.1002/pits.10021

Crespi, T. D., \& Dube, J. M. B. (2006). Clinical Supervision in School Psychology, The Clinical Supervisor, 24(1-2), 115-135. doi:10.1300/J001v24n01

Crespi, T. D., \& Fischetti, B. a. (1997). Clinical Supervision for School Psychologists: Bridging Theory and Practice. School Psychology International, 18(1), 41-48. doi:10.1177/0143034397181004

Dunsmuir, S., \& Leadbetter, J. (2010). Professional Supervision : Guidelines for Practice for Leicester: The British Psychological Society.

Eshel, Y., \& Koriat, A. (2001). The Informal Curriculum: The Latent Aspect of Psychological Training. School Psychology International, 22(4), 387-400. doi: $10.1177 / 0143034301224001$

Fouad, N. A., Grus, C. L., Hatcher, R. L., Kaslow, N. J., Hutchings, P. S., Madson, M. B., ... Crossman, R. E. (2009). Competency benchmarks: A model for understanding and measuring competence in professional psychology across training levels. Training and Education in Professional Psychology, 3(4, Suppl), S5-S26. doi:10.1037/a0015832

Haboush, K. L. (2003). Group Supervision of School Psychologists in Training. School Psychology International, 24(2), 232-255. doi:10.1177/0143034303024002007 


\section{SUPERVISION FOR SCHOOL PSYCHOLOGISTS IN TRAINING}

Hawkins, P., \& Shohet, R. (2006). Supervision in the helping professions. Glasgow: Bell and Bain Ltd.

HCPC. (2014). Standards of education and training. London: Health and Care Professions Council

Heaney, K. (2010). Investing of in the future? An exploration of trainee educational psychologists' perceptions of fieldwork supervision. University of Cardiff: Unpublished doctoral thesis.

Hill, V., Bond, C., Atkinson, C., Woods, K., Gibbs, S., Howe, J., \& Morris, S. (2015). Developing as a practitioner: How supervision supports the learning training, Educational and Child Psychology, 32(3), 119-130.

Holloway, E. L. (1995). Clinical supervision: A systems approach. Thousand Oaks, CA: Sage.

Jimerson, S. R., Oakland, T. D., \& Farrell, P. T. (Eds.). (2007). The Handbook of International School Psychology. Thousand Oaks: Sage.

Kadushin, A. (1992). Supervision in Social Work (3rd edn). New York: Columbia University Press.

Ladany, N. (2004). Psychotherapy supervision: What lies beneath. Psychotherapy Research : Journal of the Society for Psychotherapy Research, 14(1), 1-19. doi:10.1093/ptr/kph001

Lam, S.-F., \& Yuen, M. (2004). Continuing Professional Development in School Psychology: Perspective from Hong Kong. School Psychology International, 25(4), 480-494. doi:10.1177/0143034304048781

Maxwell, T. (2013). A reflection on the work of an Educational Psychologist in providing supervision for a team of community based support workers, supporting families with vulnerable adolescents at risk of exclusion from school. Pastoral Care in Education, 31(1), 15-27. doi:10.1080/02643944.2012.731425

McIntosh, D. E., \& Phelps, L. (2000). Supervision in School Psychology: Where will the future take us? Psychology in the Schools, 37(1), 33-38. doi: 10.1002/(SICI)15206807(200001)37:1<33::AID-PITS4>3.0.CO;2-F

Mehr, K. E., Ladany, N., \& Caskie, G. I. L. (2010). Trainee nondisclosure in supervision: What are they not telling you? Counselling and Psychotherapy Research, 10(2), 103113. doi:10.1080/14733141003712301

National Association of School Psychologists. (2010). Standards for Graduate Preparation of School Psychologists. Bethsda, MD: National Association of School Psychologists.

National College for Teaching \& Leadership. (2013). Educational Psychology Equal Opportunities Data 2013 cohort. London: National College for Teaching \& Leadership. 


\section{SUPERVISION FOR SCHOOL PSYCHOLOGISTS IN TRAINING}

Newman, D. S. (2013). Demystifying the School Psychology Internship: A Dynamic Guide for Interns and Supervisors. New York: Routledge.

Osborne, C., \& Burton, S. (2014). Emotional Literacy Support Assistants' views on supervision provided by educational psychologists: what EPs can learn from group supervision. Educational Psychology in Practice, 30(2), 139-155. doi:10.1080/02667363.2014.899202

Palomo, M., Beinart, H., \& Cooper, M. J. (2010). Development and validation of the Supervisory Relationship Questionnaire (SRQ) in UK trainee clinical psychologists. The British Journal of Clinical Psychology, 49(Pt 2), 131-49. doi:10.1348/014466509X441033

Papacosta, E. A. (2007). School Psychology in Cyprus. In S. R. Jimerson, T. D. Oakland, \& P. T. Farrell (Eds.), The Handbook of International School Psychology. Thousand Oaks: Sage.

Sayeed, Z. N., \& Lunt, I. (1992). Induction and Supervision for Newly Qualified Educational Psychologists. Educational Psychology in Practice, 8(3), 156-164. doi:10.1080/0266736920080305

Scaife, J. (2009). Supervision in the Mental Health Professions: A Practitioner's Guide (2nd ed). Hove: Routledge.

Simon, D. J., Cruise, T. K., Huber, B. J., Swerdlik, M. E., \& Newman, D. S. (2014). Supervision in school psychology: the developmental/ecological/problem-solving model. Psychology in the Schools, 51(6), 636-646. doi:10.1002/pits

Smith Harvey, V., \& Pearrow, M. (2010). Identifying challenges in supervising school psychologists. Psychology in the Schools, 47(6). doi:10.1002/pits

Smith Harvey, V., \& Stuzziero, J. A. (2008). Professional Develelopment and Supervision of School Psychologists: from Intern to Expert. Thousand Oaks, California: National Association of School Psychologists.

Stevens, J. (2002). Applied Multivariate Statistics for the Social Sciences. . New Jersey: LEA.

Stoltenburg, C. D., \& McNeill, B. W. (2009). IDM supervision: An integrative developmental model for supervising counselors and therapists (3rd ed). New York: Routledge.

Thielking, M., Moore, S., \& Jimerson, S. R. (2006). Supervision and Satisfaction Among School Psychologists: An Empirical Study of Professionals in Victoria, Australia. School Psychology International, 27(4), 405-414. doi:10.1177/0143034306070426

Woods, K., Atkinson, C., Bond, C., Gibbs, S., Hill, V., Howe, J., \& Morris, S. (2015). Practice Placement Experiences and Needs of Trainee Educational Psychologists in England. International Journal of School \& Educational Psychology, 3(2), 85-96. doi:10.1080/21683603.2014.956955 
SUPERVISION FOR SCHOOL PSYCHOLOGISTS IN TRAINING 


\section{SUPERVISION FOR SCHOOL PSYCHOLOGISTS IN TRAINING}

Table 1

Alignment between survey items and themes and concepts identified by Woods et al (2015)

\begin{tabular}{|c|c|c|}
\hline Theme & Key concepts & Survey items \\
\hline $\begin{array}{l}\text { Context and } \\
\text { governance }\end{array}$ & $\begin{array}{l}\text { Commitment to supervisory process } \\
\text { Professional body requirements for supervision seen as essential } \\
\text { Access to supervision protected by University requirements } \\
\text { Influence of service context }\end{array}$ & $\begin{array}{l}\text { - } \quad \text { The time allotted for my supervision is sufficient for my needs } \\
\text { - } \quad \text { In my placement service supervision time for qualified EPs is protected } \\
\text { - } \quad \text { My supervisor is fully aware of the University requirements for the placement }\end{array}$ \\
\hline $\begin{array}{l}\text { Supervisor } \\
\text { qualities and } \\
\text { characteristics }\end{array}$ & $\begin{array}{l}\text { Interpersonal characteristics of a good supervisor } \\
\text { Trust and a sense of security } \\
\text { Managing service expectations } \\
\text { Valuing different styles and approaches to practice }\end{array}$ & $\begin{array}{l}\text { - Too much time in supervision is spent checking administrative matters } \\
\text { - } \quad \text { My supervisor wants to be a supervisor for Trainee EPs } \\
\text { - In supervision I always feel my supervisor listens to me }\end{array}$ \\
\hline $\begin{array}{l}\text { Management and } \\
\text { practical } \\
\text { arrangements }\end{array}$ & $\begin{array}{l}\text { Clarification of expectations, entitlements, access and time } \\
\text { demands } \\
\text { Formal and informal supervisory support } \\
\text { Flexible and responsive support } \\
\text { Opportunities to observe and to be observed }\end{array}$ & $\begin{array}{l}\text { - My supervisor and I sometimes co-work } \\
\text { - Supervision for me has a clear purpose and structure } \\
\text { - I receive regular feedback on my applied psychology practice, based on my } \\
\text { supervisor's direct observation of my work }\end{array}$ \\
\hline $\begin{array}{l}\text { Models and } \\
\text { processes }\end{array}$ & $\begin{array}{l}\text { Value of exploring different theoretical orientations and } \\
\text { approaches to supervision } \\
\text { Development of competence in relation to models } \\
\text { Opportunities for collaboration and challenge } \\
\text { Opportunities to work with other experienced practitioner } \\
\text { colleagues }\end{array}$ & $\begin{array}{l}\text { - } \quad \text { Clearly articulated supervisory models and / or frameworks are used to } \\
\text { structure my supervision } \\
\text { - } \quad \text { In supervision we explore possibilities } \\
\text { - } \quad \text { My supervisor gives me feedback on how others see me }\end{array}$ \\
\hline $\begin{array}{l}\text { Educative } \\
\text { development }\end{array}$ & $\begin{array}{l}\text { Role of supervision in the development of evidence-based practice } \\
\text { and the application of psychological theory } \\
\text { Improved awareness of psychological models and approaches } \\
\text { Development of professional identity } \\
\text { Opportunity to progress beyond case formulations to explore other } \\
\text { psychological dimensions (e.g. ethics) }\end{array}$ & $\begin{array}{l}\text { - } \quad \text { Supervision helps me reflect on my learning and practice } \\
\text { - } \quad \text { My supervisor frequently asks about the professional ethics of my work } \\
\text { - } \quad \text { Supervision is helping integrate different aspects of psychology in my practice }\end{array}$ \\
\hline $\begin{array}{l}\text { Supportive and } \\
\text { affective } \\
\text { dimensions }\end{array}$ & $\begin{array}{l}\text { Quality of supervisory relationship } \\
\text { Opportunities to be open and honest about practice experiences } \\
\text { Emotional experience of developing a new role (containing anxiety } \\
\text { and boosting confidence) }\end{array}$ & $\begin{array}{ll}\text { - } & \text { Supervision builds my confidence } \\
\text { - } & \text { In supervision I feel I can talk about the emotional impact of work } \\
\text { - } & \text { Supervision is a safe place in which to talk and reflect honestly }\end{array}$ \\
\hline
\end{tabular}




\section{SUPERVISION FOR SCHOOL PSYCHOLOGISTS IN TRAINING}

\begin{tabular}{|c|c|c|}
\hline & Development of supervisory relationship over time & \\
\hline Outcomes & $\begin{array}{l}\text { Practical, theoretical and affective outcomes } \\
\text { Meta-learning opportunities } \\
\text { Process equips trainees for healthy and sustainable working } \\
\text { practices } \\
\text { Development of a coherent model of applied psychology practice } \\
\text { Ability to reflect on and apply ethical principles and frameworks }\end{array}$ & $\begin{array}{l}\text { - Through supervision I gain perspectives on my developmental needs as an } \\
\text { applied psychologist } \\
\text { - } \quad \text { In supervision my supervisor teaches me how to do specific work } \\
\text { - Supervision helps me understand my role in the Local Authority }\end{array}$ \\
\hline
\end{tabular}


SUPERVISION FOR SCHOOL PSYCHOLOGISTS IN TRAINING

Table 2

Demographic information

\begin{tabular}{|c|c|c|}
\hline $\begin{array}{l}\text { Year of } \\
\text { Training }\end{array}$ & Gender & Number \\
\hline
\end{tabular}

\begin{tabular}{|c|c|c|c|}
\hline \multirow{4}{*}{$\underline{1}$} & Female & 83 & $27.1(7.8)$ \\
\hline & Male & 21 & $28.1(8.1)$ \\
\hline & Undeclared & 7 & $32.4(8.8)$ \\
\hline & Total & 111 & $27.6(8.0)$ \\
\hline \multirow{4}{*}{$\underline{2}$} & Female & 84 & $27.8(7.3)$ \\
\hline & Male & 8 & $27.8(2.1)$ \\
\hline & Undeclared & 6 & $29.0(3.2)$ \\
\hline & Total & 98 & $27.9(6.8)$ \\
\hline \multirow{4}{*}{$\underline{3}$} & Female & 82 & $27.7(8.0)$ \\
\hline & Male & 11 & $30.7(5.4)$ \\
\hline & Undeclared & 8 & 24.5 (10.1) \\
\hline & Total & 101 & $28.2(8.7)$ \\
\hline \multirow{4}{*}{ Total } & Female & 249 & $27.7(8.0)$ \\
\hline & Male & 40 & $28.7(6.6)$ \\
\hline & Undeclared & 21 & $28.4(8.6)$ \\
\hline & Total & 310 & $27.9(7.9)$ \\
\hline
\end{tabular}




\section{SUPERVISION FOR SCHOOL PSYCHOLOGISTS IN TRAINING}

Table 3

Oblique rotation pattern matrix

\begin{tabular}{|c|c|c|c|c|c|}
\hline Questionnaire item & $\begin{array}{c}\text { Thematic } \\
\text { analysis themes }\end{array}$ & $\mathrm{M}(\mathrm{SD})$ & $\begin{array}{l}\text { Component } 1 \\
\text { [Safe space for } \\
\text { authentic learnins }\end{array}$ & $\begin{array}{l}\text { Component } 2 \\
\text { [Instructional } \\
\text { support] }\end{array}$ & $\begin{array}{c}\text { Component } 3 \\
\text { [Reference points for } \\
\text { professional learning] }\end{array}$ \\
\hline In supervision I always feel my supervisor listens to me & SQ & $4.45(1.17)$ & .81 & & \\
\hline In supervision we explore possibilities & MP & $4.30(.92)$ & .79 & & \\
\hline In supervision I feel I can talk about the emotional impact of work & SA & $4.00(1.12)$ & .78 & & \\
\hline Supervision helps me reflect on my learning and practice & ED & $4.30(1.03)$ & .77 & & \\
\hline Supervision builds my confidence & SA & $4.35(.99)$ & .77 & & \\
\hline Supervision is a safe place in which to talk and reflect honestly & SA & $4.10(1.02)$ & .72 & & \\
\hline Too much time in supervision is spent checking administrative matters ${ }^{b}$ & $S Q$ & $2.20(1.28)$ & -.71 & & \\
\hline My supervisor is fully aware of the University requirements for the placement & CG & $3.90(1.17)$ & .66 & & \\
\hline Supervision is helping integrate different aspects of psychology in my practice & ED & $3.90(.97)$ & .64 & & \\
\hline The time allotted for my supervision is sufficient for my needs & CG & $4.15(.59)$ & .63 & & \\
\hline Supervision for me has a clear purpose and structure & PA & $3.72(.63)$ & .62 & & \\
\hline Supervision helps me understand my role in the Local Authorityc & O & $3.85(1.14)$ & .50 & & \\
\hline In my placement service supervision time for qualified EPs ${ }^{d}$ is protected & CG & $3.75(1.29)$ & .44 & & \\
\hline My supervisor wants to be a supervisor for TEPs ${ }^{e}$ & $S Q$ & $4.35(.88)$ & .43 & & \\
\hline My supervisor and I sometimes co-work. & $\mathrm{PA}$ & $2.65(1.29)$ & & .84 & \\
\hline $\begin{array}{l}\text { I receive regular feedback on my applied psychology practice, based on my } \\
\text { supervisor's direct observation of my work }\end{array}$ & PA & $2.85(1.46)$ & & .72 & \\
\hline In supervision my supervisor teaches me how to do specific work & $\mathrm{O}$ & $3.30(1.03)$ & & .45 & .38 \\
\hline My supervisor gives me feedback on how others see me & MP & $3.50(1.32)$ & & & .71 \\
\hline My supervisor frequently asks about the professional ethics of my work & ED & $3.40(.99)$ & & & .62 \\
\hline $\begin{array}{l}\text { Clearly articulated supervisory models and / or frameworks are used to structure } \\
\text { my supervision }\end{array}$ & MP & $2.55(1.15)$ & & & .59 \\
\hline $\begin{array}{l}\text { Through supervision I gain perspectives on my developmental needs as an } \\
\text { applied psychologist }\end{array}$ & $\mathrm{O}$ & $4.10(1.92)$ & - & - & - \\
\hline Eigenvalue & & & 7.34 & 2.43 & 3.21 \\
\hline$\alpha$ & & & .85 & .64 & .55 \\
\hline$\%$ of variance & & & 38.4 & 7.23 & 5.56 \\
\hline
\end{tabular}

Notes:

${ }^{a} \mathrm{CG}=$ Context \& Governance; $\mathrm{SQ}=$ Supervisor Qualities \& Characteristics; $\mathrm{PA}=$ Practical Arrangements; MP=Models \& Processes;

$\mathrm{ED}=$ Educative Development; SA=Supportive \& Affective Dimensions; O=Outcomes. See Woods et al. (2015) for details.

$\mathrm{b}$ This item is reverse scaled.

${ }^{c}$ Local authorities are the government office regions in which UK school psychologists work.

${ }^{\mathrm{d}}$ Educational psychologists

e Trainee educational psychologists 
Table 4:

Component Correlation Matrix

\begin{tabular}{lccc}
\hline & $\begin{array}{c}\text { Safe space for } \\
\text { authentic } \\
\text { learning }\end{array}$ & $\begin{array}{c}\text { Instructional } \\
\text { support }\end{array}$ & $\begin{array}{c}\text { Reference } \\
\text { points for } \\
\text { professional } \\
\text { learning }\end{array}$ \\
\hline Safe space for authentic learning & 1 & & \\
Instructional support & $.411^{* *}$ & 1 & \\
Reference points for professional learning & $.474^{* *}$ & $.385^{* *}$ & 1 \\
\hline Note. ${ }^{* *}$. p<0.01 level (2-tailed) & & &
\end{tabular}

Table 5:

Component Correlations within each year of training

\begin{tabular}{lll} 
Safe space & Instructional & Reference \\
for & support & points for \\
authentic & & professional \\
learning & & learning \\
\hline
\end{tabular}

1. Safe space for authentic learning

$\begin{array}{ll}\text { Year } 1 & 1 \\ \text { Year } 2 & 1 \\ \text { Year } 3 & 1\end{array}$

2. Instructional support

$\begin{array}{lll}\text { Year } 1 & .681^{* *} & 1 \\ \text { Year } 2 & .364^{* *} & 1 \\ \text { Year 3 } & .261^{* *} & 1\end{array}$

3. Reference points for professional learning

\begin{tabular}{llll} 
Year 1 & $.489 * *$ & $.438^{* *}$ & 1 \\
Year 2 & $.480^{* *}$ & $.376^{* *}$ & 1 \\
Year 3 & $.444^{* *}$ & $.402^{* *}$ & 1 \\
\hline
\end{tabular}


Table 6:

Component Mean and standard deviation: percentage of maximum by year of training

\begin{tabular}{lllll}
\hline & Year 1 & Year 2 & Year 3 & Total \\
\hline 1. Safe space for authentic & 75.2 & 75.4 & 77.6 & 76.0 \\
learning & $(12.9)$ & $(13.8)$ & $(13.7)$ & $(13.5)$ \\
2. Instructional support & 68.8 & 60.6 & 58.8 & 63.0 \\
3. Reference points for & $(18.4)$ & $(17.6)$ & $(18.8)$ & $(18.8)$ \\
professional learning & 58.7 & 57.9 & 60.9 & 59.2 \\
\hline
\end{tabular}




\section{SUPERVISION FOR SCHOOL PSYCHOLOGISTS IN TRAINING}

Appendix: Questionnaire:

\section{Trainee Educational Psychologists' experience of supervision}

\begin{tabular}{|c|c|c|c|c|}
\hline & $\begin{array}{l}\text { Di } \\
\text { the questio } \\
\text { responses i } \\
\text { disagree" t } \\
\text { the continu }\end{array}$ & $\begin{array}{l}\text { by } \mathrm{r} \\
\text { Imn } \\
\text { ally }\end{array}$ & $\begin{array}{l}\text { Ith } \\
\text { ang } \\
\text { eac }\end{array}$ & i) \\
\hline & 1 & 2 & 3 & 4 \\
\hline $\begin{array}{l}1 . \quad \text { The time allotted for my supervision is sufficient for my } \\
\text { needs (CI) }\end{array}$ & & & & \\
\hline My supervisor and I sometimes co-work (PA). & & & & \\
\hline $\begin{array}{l}\text { 3. Clearly articulated supervisory models and / or } \\
\text { frameworks are used to structure my supervision (MP) }\end{array}$ & & & & \\
\hline $\begin{array}{l}4 . \quad \text { In my placement service supervision time for qualified EP } \\
\text { is protected }(C G)\end{array}$ & & & & \\
\hline $\begin{array}{l}5 . \quad \text { My supervisor is fully aware of the University } \\
\text { requirements for the placement (CG). }\end{array}$ & & & & \\
\hline $\begin{array}{l}\text { 6. Too much time in supervision is spent checking } \\
\text { administrative matters (SQ) }\end{array}$ & & & & \\
\hline $\begin{array}{l}7 . \\
\text { (ED). }\end{array}$ & & & & \\
\hline $\begin{array}{l}\text { 8. My supervisor frequently asks about the professional } \\
\text { ethics of my work (ED). }\end{array}$ & & & & \\
\hline $\begin{array}{l}\text { 9. Through supervision I gain perspectives on my } \\
\text { developmental needs as an applied psychologist }(O)\end{array}$ & & & & \\
\hline $\begin{array}{l}\text { 10. Supervision is helping integrate different aspects of } \\
\text { psychology in my practice (ED) }\end{array}$ & & & & \\
\hline 11. Supervision builds my confidence (SA) & & & & \\
\hline 12. In supervision we explore possibilities (MP) & & & & \\
\hline $\begin{array}{l}\text { 13. My supervisor gives me feedback on how others see me } \\
\text { (MP) }\end{array}$ & & & & \\
\hline $\begin{array}{l}\text { 14. My supervisor wants to be a supervisor for Trainee EPs } \\
\text { (SQ) }\end{array}$ & & & & \\
\hline $\begin{array}{l}\text { 15. In supervision my supervisor teaches me how to do } \\
\text { specific work (O) }\end{array}$ & & & & \\
\hline $\begin{array}{l}\text { 16. Supervision helps me understand my role in the Local } \\
\text { Authority }(\mathrm{O})\end{array}$ & & & & \\
\hline $\begin{array}{l}\text { 17. In supervision I feel I can talk about the emotional impact } \\
\text { of work (SA). }\end{array}$ & & & & \\
\hline 18. Supervision for me has a clear purpose and structure (PA). & & & & \\
\hline $\begin{array}{l}\text { 19. In supervision I always feel my supervisor listens to me } \\
\text { (SQ) }\end{array}$ & & & & \\
\hline $\begin{array}{l}20 . \quad \text { I receive regular feedback on my applied psychology } \\
\text { practice, based on my supervisor's direct observation of my work } \\
\text { (PA). }\end{array}$ & & & & \\
\hline $\begin{array}{l}\text { 21. Supervision is a safe place in which to talk and reflect } \\
\text { honestly (SA). }\end{array}$ & & & & \\
\hline
\end{tabular}

Notes: $\mathrm{CG}=$ Context \& Governance; $\mathrm{SQ}=$ Supervisor Qualities \& Characteristics; PA=Practical

Arrangements; MP=Models \& Processes; ED=Educative Development; $S A=S u p p o r t i v e ~ \& ~ A f f e c t i v e$

Dimensions; O=Outcomes; EPs=educational psychologists 




Figure 1: Seven main themes representing trainee psychologists' experiences and needs within practice placement supervision (from Woods et al., 2015) 


\section{SUPERVISION FOR SCHOOL PSYCHOLOGISTS IN TRAINING}

80

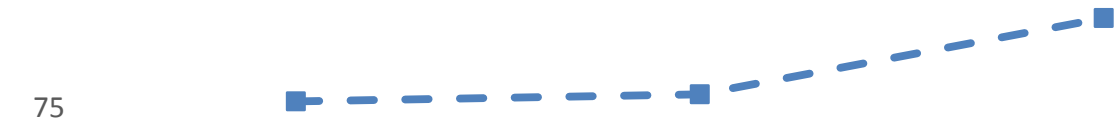

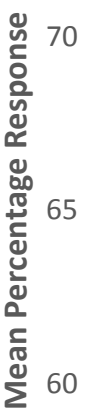

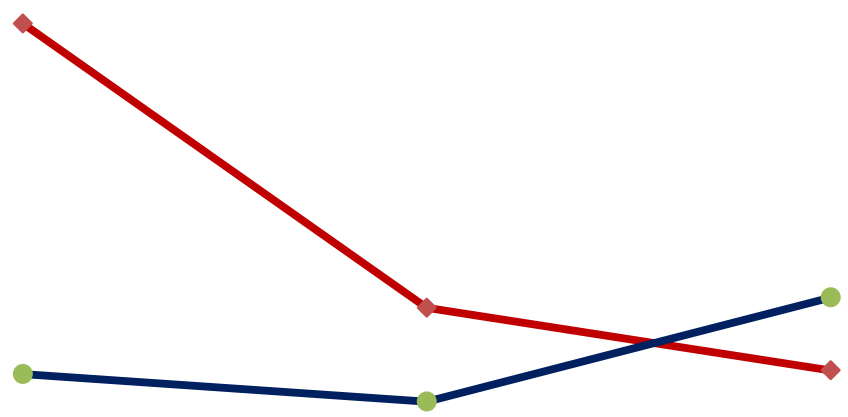

55

50

Trainee Cohort

- Safe space for authentic learning

$\longrightarrow$ Instructional Support

- Reference Points for Professional Learning

Figure 2. Summary of Supervision Component Means by Year of Training 


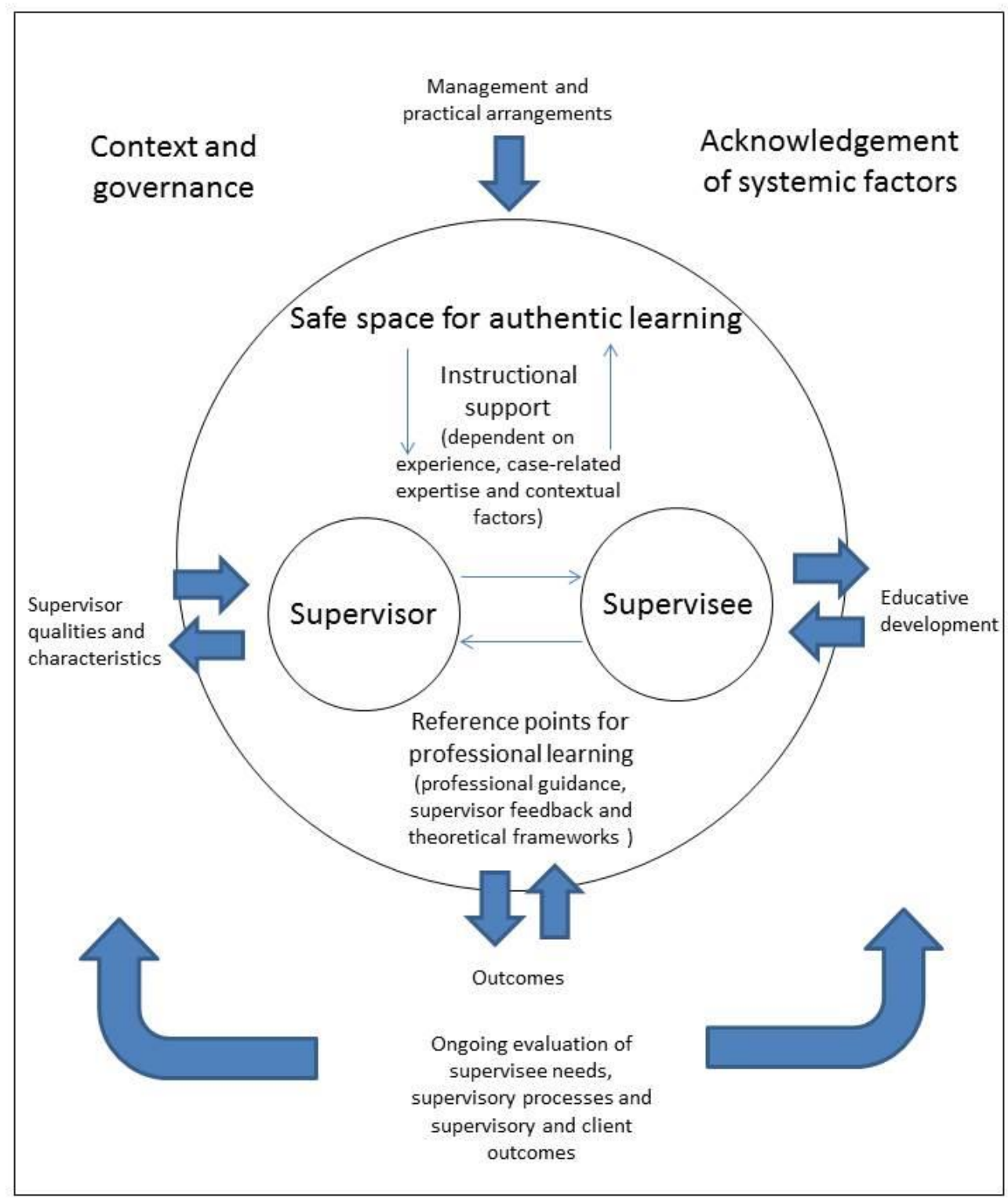

Figure 3: Theoretical framework developed from the Exploratory Factor Analysis, emergent factors (Woods et al., 2015) and a review of existing literature. 